\title{
The Resistance of Traditional Value at Kajang Community in Globalization Era
}

\author{
Nursalam \\ Faculty of Teacher, Training and Education, \\ Makassar Muhammadiyah of University, South Sulawesi, INDONESIA \\ nursalam.fkip@gmail.com
}

\begin{abstract}
Socio-cultural change in the era of globalization is characterized by the structural changes in social and cultural patterns in a community as well as the change in the substance of will have implications on people's lives. But things are different for the people of Kajang, where traditional values are maintained and preserved although it has been hit by globalization, even custom which become a key social processes in the community. The research was a descriptive qualitative method. The research aims the existence of traditional value at Kajang community in globalization era. This research was conducted in Kajang Bulukumba, South Sulawesi, Indonesia. The results showed that, in the Kajang community culture that is so strong and condensed so that the modernization cannot affect cultural and social value local communities. Even the development of modernization still run but the resistance still occurs in Kajang community, it caused by several factors, including: factor unconsciousness individuals about the importance of technology in the modern era. Moreover, customary law so that the strong factor in solving the problems, state law is not valid on the community. From the aspect of modernization, in order to avoid the influence of modernists are externally towards society Kajang, these communities through the head the customary more intense do doctrine to the community and more hieratic their culture in every celebration as a religious event, ceremony marital, the patterns of adaptation in communication and patterns of adaptation activities economy.
\end{abstract}

\section{Keywords: Existence, Traditional Values, Globalization}

\section{INTRODUCTION}

The environment, human beings are the most dominant element in a life. Salim said that the environment includes the caused by the interaction of living organisms with the environment. Living organism composed of human beings, animals and plants that individually or collectively influence and are influenced by the environment

Social and cultural change is a symptom of the changing structure of the social and cultural patterns in a society. Socio-cultural changes are common symptoms that occur all time in every society. Changes that occur in accordance with the nature and human nature that always wants to make changes. [1]
Tanatoa community still clings to the traditional fully Ammatoa. They practice a very simple way of life by rejecting everything that related to the technology. For them, the objects of technology can bring negative impact to their lives because it is destructive the eternal of natural resources. Communities are always using black clothes is then referred to as indigenous peoples of Ammatoa.[2]

By looking at reality in the Kajang community, it can be said that the Kajang still maintenance the rules that made by their ancestor. It was made the researcher interested doing investigation about the Kajang community resentencing their culture in globalization era with the tittle "The Resistance of Traditional Values at Kajang Community in Globalization Era"

\section{REVIEW OF LITERATURE}

The essential meaning of modernization is a modern social structure which processing becomes modern. [3] if modernization has a field meaning, including the process for getting new image like image about changing or development issue in social life.

In general, there are the characteristics of modernity that can be applied in all forms of society [3] , the level of economic development continues, at least regarding the production and consumption remain, the levels of popular participation in governance is adequate, the diffusion of norms secular - rational culture, increased mobility in society, as well as the transformation of the individual 's personality, so it can function effectively in the social order in accordance with the demands of modernity

Modernization included a total transformation in together life which traditional or pre modern in social organization and technology statement. Behavior, actions, and actions are not a spontaneous performance, without the ability and quality, but an appearance of confidence and confidence will progress and updates that must be done [4]. Therefore, new things and being run in life, is an input that must be processed in accordance with the conditions and challenges that characterize today's life.

The definition if non biologist modernization basically was a technological term, it was not a values 
meaning. It is concern of the human replacements labor by machine [5]. It is relating to communication and information with fast time, the movement of things with fast, processing automatically, and other behavior which make human being get good service.

Indonesian cultures have variety but it still made and influenced from others culture like European culture. The word of culture, derived from the Sanskrit word of buddhayah, the plural of buddhi which means "kindness" or "eternal" [6] According to BAKKER the word of culture of "Abhyudaya", the Sansekerta word "Abhyudaya" according to Sansekerta Dictionary: Results of good, progress, complete prosperity paced [7]. Culture with basic word culture comes from sangsakerta "buddhayah", which is the plural of buddhi which means "kindness" or "reasonable". So, Koentjaraningrat, defines culture as "the power of gratitude" in the form of creativity, initiative and flavor, while culture is the result of creativity, initiative and a sense of it [8].

Culture of Colere Latin word "cultivate", "work", and related to land or farming the same as the "culture", evolved into" "all efforts and actions of man to cultivate the land and natural change " [7].

Social action is an individual act all measures, it has meaning or subjective meaning for him and directed the actions of others individual actions directed at inanimate objects do not fall into the category of social action. Social action is an action that is clearly directed to others [9]. Social action may be an act that is thought or subjective nature that may occur due to the positive influence of a particular situation or a looping action intentionally as a result of the influence of similar situations or form of passive consent in certain circumstances.

Clearly there are five main characteristics [10], including as a social action, namely: (1) if human actions, according to the subjective meaning actors and this can include a wide range of action, (2) the real action can be thought completely, (3) actions that can be derived from the result of a positive influence on a situation, repeated deliberate action, or action in the form of tacit approval of any party, (4) the action was directed to someone or to some individual, and (5) the action regard the actions of others and directed to someone else's. In addition to the five principal characteristics, according to Weber, social action can also be distinguished from the point of time so no action is directed to the present, past, or future. The target of a social action can be individual but also group or a group of people. Weber distinguishes human social action into four types (Ritzer, 2005). According to him, the more rational action was the more easily understood. Four types of social actions in question are: (1) the purpose of the rational action, (2) the value of rational action, (3) effective action, and (4) traditional action. In a rational action objective, actors assess and determine the purpose and course of action that could be used as a means to achieve other goals. Rational action values, actors in choosing how already specify the desired destination.

\section{RESEARCH METHODS}

According to Guba and Lincoln (2009) [11] and Ponterotto, 2005) philosophy of qualitative research from the standpoint of epistemology: emphasize assumptions about the relationship between researchers and researched to find out the traditional value of society of Kajang in the era of modernization, while from the aspect of ontology: pressure from the viewpoint of assumptions about what is behind the visible, it can be done through question and in-depth study of the existence of cultural values of society awning, and axiology; This research emphasizes on the assumption that the value of the position, ethical, moral choice investigator of the study.

Through a philosophy of qualitative research, this study used qualitative research methods with case study research approach and phenomenology. This type of research is a method that is considered appropriate so that researchers can directly describe the various words written or spoken by people and observed behavior (Creswell, 2007; Cozby, 2009; Yin, 2008) [12].

The choice of location Bulukumba in South Sulawesi as a district inhabited by Kajang community, is also regarded as the District Still Condensed culture of his or her custom. Respondents in this study of 10 people consisting of a custom shop, chieftains, religious stores and government and society.

Credibility the data, the researchers examined the data using triangulation method is to connect theory and research results with results of previous studies. Besides a re-examination carried out repeatedly between the results of the analysis of the data with previous data. Researchers further discussions with experts about the research that has been done.

Analysis of the data used in this research is qualitative descriptive technique. That is the data of documents, interviews and observations were analyzed using an open coding, cross and selected using NVivo software. stated that the analysis of data in a qualitative study of all data obtained from interviews, observation and documents, the researchers explain, analyze, interpret, explain, that has to do with research focus.

\section{RESEARCH FINDINGS}

Tanatoa village has homogeneous population structure in the village. It is dominated by young and productive age, these circumstances provide a different social perspective future will come, mainly caused by the education sector, and enable to develop the potential Tanatoa village. Based on data of Tanatowa village noted that in February 2013 the population in the village 
of 4096 live in Tanatowa village which composed of men and women in 1923 people 2173 people.

Kajang community has physical characteristic with black clothes and do not wear sandals, Kajang Community modesty inherent in everyday life, they build a house with a very open, house built no walls like a modern home, every home contains only the following ladder entrance at the front. On the inside there is no room, there is only a kitchen located at the front of the house just to the left of the entrance. The placement of the kitchen near the door is containing philosophical that man glorifies kitchen Kajang as a source of life. The absence of a room divider has a meaning that the Kajang want to show the attitude of openness to the guests who come.

\section{TRaditional Values OF KAJANG COMMUNity IN GLOBALIZATION ERA}

\section{a) Belief systems}

All of that is the essence of true religion, conceived by "sampajangtamattappuje'netalluka". It meant prayer that never stop, ablution never cancelled. While the five daily prayers for those just acts alone.

\section{b) Individual consciousness}

The levels and direction of change in a society heavily influenced by the needs and public awareness of it. In Kajang community, awareness of it occurs in traditional leaders or community leaders, the change process easier. Consciousness also as a form of internalization process in public life.

\section{c) Cultivation}

As for how farming is done by the indigenous peoples ammatowa is the same as that carried out by citizens who exist outside ammatowa region, where only fished in the eastern summer time where high rainfall is caused by the location of ammatowa village is hilly terrain. The only difference lies in the management of land outside the region where the community is using modern technology such as the tractor while the area using the area just like buffalo cattle and horses.

\section{PATTERNS COMMUNITY ADAPTATION KAJANG TO STAY RESISTANCE IN THE ERA OF GLOBALIZATION}

\section{a) Adaptation pattern on Religious Affairs}

In social relations in the religious affairs Kajang tribe is rate quite rarely follows the events or activities of a religious nature, but they only follow events or religious activities according to the teachings Ammatoa, but society at large Kajang tribe converted to Islam, so that they appreciate the month of fasting, prayer time which determined the teachings of Islam, and pay zakat, even in Kajang tribe there is going to perform the Hajj.

\section{b) Pattern Adaptation in Economic Activity}

Ammatoa indigenous livelihoods, in general, farmers, ranchers, some small traders, carpentry, and employees. Location rice paddies and fields they are quite far from where she lived about 1-7 km. Farmers generally do their own paddy fields. Women work weaving (sarong and scarves) with ingredients of weaving derived from Tarum plants that they grow themselves.

\section{c) Pattern Adaptation on Mutual Cooperation} Activities

In social relationships for mutual assistance activities, Kajang rate sufficiently contributes in taking part in the role of mutual assistance in Tanatoa. From the post reflected their philosophy three patterns of relationships between citizens' ammatowa, that togetherness, interest groups and similarity. Their relationship with the government of an underlying principle that no government essentially ugly, everything is fine.

d) Adaptation pattern on the Marriage Ceremony Event/Folklore

In social relations for the marriage ceremony / Kajang tribe custom is often to participate in an event carried out other tribes. Participation they are doing because they are often invited to the outside community when invited. If invited by the outside community in the activities of the wedding / tribal Kajang definitely attend and participate in these activities.

\section{e) Pattern Adaptation in Communicating}

Language as a communication tool of Kajang tribe include using KonjoBugis language. Language was a bit different from other languages of archipelago because the language of Kajang tribe will be understood by those who were there, but Kajang Tribe communities are able to communicate with outsiders, such as Bugis Makassar language or Indonesian or official language, it indicates that the Kajang communities able to make adaptation with the residents from outside unable to communicate with Konjo language itself.

\section{CONCLUSION}

Communities that exist in the region are substantially culture is still very strong, in spite of the modernization. But will not affect the cultural and social values of Kajang. As for the bond in resisting every onslaught of modernization is known as the so-called "pasang". Traditional values are still resistant to is, people still wear all black, indigenous peoples of Kajang despite knowing the equipment in the fields of modern agriculture, but they are still using the traditions what they get from ancestors. That's all for the sake of keeping social value in the community of Kajang tribe in order to remain resistant. The factors that cause thus remain resistant are, individual consciousness, do not 
accept modern technology, strict sanctions in case of violations and they obey the rules that already exist in the teachings of Passang. The pattern of adaptation in Kajang Tribe community, including on: Patterns of religious adaptation, adaptation to the activity pattern of the marriage ceremony/tradition, patterns of adaptation in communication and patterns of adaptation in economic activity.

\section{REFERENCES}

[1] Sztompka, P. (2005). Sociology of Social Change. Jakarta: Prenada.

[2] Widyasmoro, T.T, (2006). "Kajang, Bedouin from Sulawesi"'(Online)http:// www. Intisari -online.com. Diakses $09 / 11 / 2014$

[3] Lauer, H. R. (1992).Perspectives on the Social Cultural Change. Rineka Cipta Jakarta.

[4] Abdulsyani. (2002). Systematic Theory and Applied Sociology.Jakarta : PT Bumi Aksara.

[5] Horowitz, D. L. (1985). Ethnic Groups in Conflict. Berkeley: University of California Press.

[6] Koentjaraningrat. (1990). History of Anthropological Theory. Universitas Indonesia Pers. Jakarta.

[7] Koentjaraningrat (2003). Introduction to Anthropology -Jilid first, second printing, Jakarta: Rineka Cipta

[8] Koentjaraningrat.(2000). Cultural Mentality and Development (prints of the nineteenth), Jakarta: PT. Gramedia Pustaka Utama.

[9] Ritzer, G \& Goodman D. J. (2005). Modern Sociological Theory. Alimandan translation. Jakarta: Prenada Media.

[10] Turner, S.P. (ed). (2000). The Cambridge Companion to Weber. New York: Cambridge University Press.

[11] Ponterotto, J. G. (2005). Qualitative Research in Counseling Psychology: A Primer on Research Paradigms and Philosophy of Science. Journal of Counseling Psychology Vol.52(2), pp.126-136.

[12] Creswell, J. W. (2007). Qualitative Inquiry and Research Design: Choosing among Five Approaches $\left(2^{\text {nd }}\right.$ ed.). Thousand Oaks, C.A.: Sage Publications. 